Portland State University

PDXScholar

Rapid Change in Shallow Water Fish Species

Composition in an Historically Stable Antarctic

Environment

Bradley A. Buckley

Portland State University

Follow this and additional works at: https://pdxscholar.library.pdx.edu/bio_fac

Part of the Marine Biology Commons, and the Terrestrial and Aquatic Ecology Commons

Let us know how access to this document benefits you.

Citation Details

Buckley, B. A. (2013). Rapid change in shallow water fish species composition in an historically stable Antarctic environment. Antarctic Science, 25(5), 676-680.

This Article is brought to you for free and open access. It has been accepted for inclusion in Biology Faculty Publications and Presentations by an authorized administrator of PDXScholar. Please contact us if we can make this document more accessible: pdxscholar@pdx.edu. 


\title{
Rapid change in shallow water fish species composition in an historically stable Antarctic environment
}

\author{
BRADLEY A. BUCKLEY \\ Center for Life in Extreme Environments, Department of Biology, Portland State University, Portland, OR 97201, USA \\ bbuckley@pdx.edu
}

\begin{abstract}
McMurdo Sound, Antarctica, is home to a unique marine biota with an ecology that has evolved in this frigid environment over millions of years. The region is one of the least disturbed, and possibly the last pristine, marine ecosystem on Earth. Here, the results of three seasons of fishing in the shallow nearshore waters of McMurdo Sound are reported. A shift in the composition of small fish species at one site, Inaccessible Island, has been observed in just five years. The shift in shallow water species composition occurred during a period that followed the maturation of a commercial fishery for the Antarctic toothfish, Dissostichus mawsoni Norman, a predator of smaller fish, and the presence of a large iceberg, termed B-15, at the mouth of McMurdo Sound during the early 2000s that trapped the annual sea ice in the area leading to the unusual accrual of multi-year sea ice. The data presented here provide a current record of species composition and physiological condition of small, shallow water fishes at three sites in McMurdo Sound, providing a current baseline for the assessment of future changes wrought by environmental changes and unprecedented fishery pressures in the Ross Sea.
\end{abstract}

Received 11 June 2012, accepted 17 December 2012, first published online 12 March 2013

Key words: Antarctic fishes, condition index, distribution, McMurdo Sound

\section{Introduction}

Located at the high latitude boundary of the Ross Sea, McMurdo Sound, Antarctica $\left(77^{\circ} \mathrm{S}\right)$ is the southernmost marine habitat on the planet. The importance of the area as a breeding location for penguins and seals and as a feeding ground for whales supports the initiation of extensive monitoring of local fish stocks, as fishes represent an important food source for these top predators (La Mesa et al. 2004). Due to the remote location of McMurdo Sound and the presence of annual sea ice, which can hinder sampling by methods such as trawling, there is a lack of interannual monitoring of the movement, distributions and abundances of local fish species. Calls have been made to add important McMurdo Sound fish species to the Ecosystem Monitoring Programme of the Convention for the Conservation of Antarctic Marine Living Resources (CCAMLR) to begin to understand the nature of the changes taking place in the ecology of the region (Ainley \& Siniff 2009).

The fishes of continental Antarctica have evolved in extreme cold for millions of years and possess profound biochemical and physiological adaptations to life at nearfreezing temperatures (Eastman \& McCune 2000, Eastman 2005, Cheng \& Detrich 2007, Petricorena \& Somero 2007). As a result, only 322 currently recognized species occur below the Polar Front and this number declines rapidly with increasing latitude (Eastman 2005). The shallow coastal waters of McMurdo Sound near Ross Island are inhabited by perhaps as few as seven to eight closely related fish species, mostly of the genus Trematomus. This group of fishes, comprising benthic and semi-pelagic species, plays a critical ecological role in the neritic ecosystem, acting as predators of the invertebrate grazers that feed on phytoplankton and sea ice algae. In turn, they are prey species for predators such as toothfish, penguins, seals and killer whales (Burns et al. 1998, La Mesa et al. 2004, Smith et al. 2007). The factors that influence the distribution and abundance of dominant local species such as the silverfish, Pleuragramma antarcticum Boulenger, the cryopelagic bald notothen Pagothenia borchgrevinki (Boulenger), and several benthic trematomid rock cod species are poorly understood. The impacts of changes in the availability of these prey species on the feeding and reproductive ecology of local seal and penguin colonies are equally unclear.

In 2005, 2010 and 2011, fishing efforts were made in shallow water (6-24 m depth) at two sites in McMurdo Sound, one on the north-western side of Inaccessible Island and a second near a steep rocky feature of Ross Island termed the Cape Evans wall (unofficial name), located south of Cape Evans. Both of these sites are in eastern McMurdo Sound near several perennial breeding colonies of Adélie penguin and Weddell seals. Efforts were also made near the jetty located in front of McMurdo Station. Catch sizes, fish morphometrics and physiological condition (Fulton's condition index $K$ ) are presented, with the goal of providing current, baseline data of the shallow water fish species at sites in McMurdo Sound. 

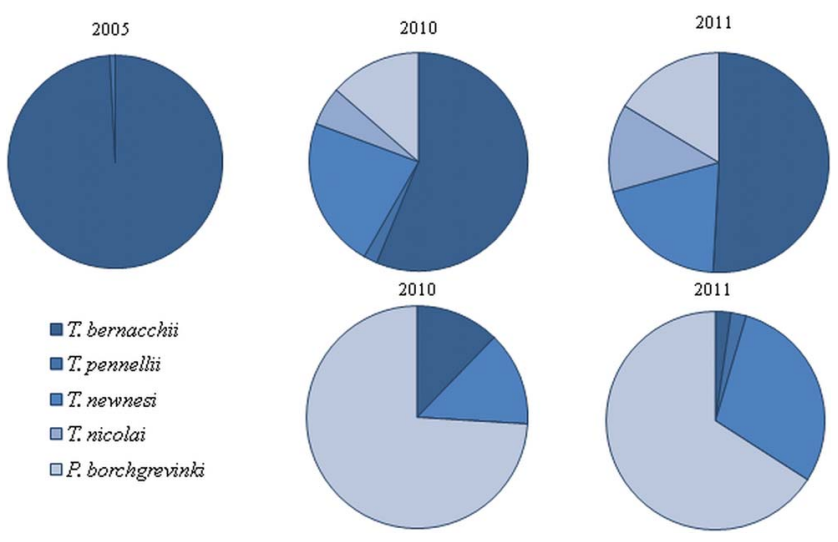

Fig. 1. Composition of fish species, depicted as percentage of total catch, collected at two sites in McMurdo Sound, located in the southern Ross Sea, Antarctica. The top three charts report species collected from Inaccessible Island and the bottom two charts report those collected at the Cape Evans wall (see text for description of locations). Years of collection are listed above each chart.

\section{Materials and methods}

\section{Collection sites, methods and dates}

Fish were collected in shallow water (12-18 m) at Inaccessible Island, McMurdo Sound, Antarctica (77³9'53"S, 166 21'75"E) through the sea ice via hook-and-line during the course of three sampling seasons (October-November 2005, 2010 and 2011). Another site in McMurdo Sound, located in Erebus Bay, south of Cape Evans proper and referred to here as the Cape Evans wall $\left(77^{\circ} 38^{\prime} 24^{\prime \prime} \mathrm{S}, 166^{\circ} 31^{\prime} 04^{\prime \prime} \mathrm{E}\right)$, was also the location of sustained research fishing efforts in the spring of 2010 and 2011. At the Cape Evans wall, our fishing efforts for benthic species were conducted in slightly deeper waters $(18-24 \mathrm{~m})$. Fishing efforts at the Cape Evans wall also included the cryopelagic zone at the seawater/sea ice interface. More limited fishing efforts were also made at the jetty directly in front of McMurdo Station ( $\left.77^{\circ} 50^{\prime} 60^{\prime \prime} \mathrm{S}, 166^{\circ} 40^{\prime} 0.0^{\prime \prime} \mathrm{E}\right)$.

\section{Morphometrics and measurement of Fulton's condition index $(K)$}

In the 2011 season, fish total length $\left(\mathrm{L}_{\mathrm{T}}\right)$ in $\mathrm{cm}$ and weight (W) in $\mathrm{g}$ were recorded for each specimen.
Fulton's condition index for each individual was calculated according to the equation:

$$
K=\left(\mathrm{W} /\left(\mathrm{L}_{\mathrm{T}}\right)^{3}\right) \times 10^{2} .
$$

The Fulton's index is utilized to describe condition as it reflects weight per unit length, so higher values of $K$ are associated with larger bodied individuals and reflect nutritional state (Weatherly \& Gill 1987, Bolger \& Connolly 1989, Busacker et al. 1990, Fenaughty 2006).

\section{Statistics}

Intra-specific differences in $\mathrm{L}_{\mathrm{T}}, \mathrm{W}$ and $K$ between individuals from different collection sites were determined via Student's $t$-test.

\section{Results}

At Inaccessible Island, the species composition of the catch from fishing efforts in 2010 and 2011 differed markedly from that of the 2005 season. In 2005, a single species, Trematomus bernacchii (Boulenger), represented nearly $100 \%$ of the catch. By 2010, five species, mostly of the genus Trematomus, were represented and the contribution of $T$. bernacchii to the sampling total had dropped to $56.3 \%$ in 2010 and to $50.9 \%$ in 2011 (Fig. 1, Table I). Fishing efforts in terms of time and personnel were comparable in 2005, 2010 and 2011, so the differences in catch probably reflect a change in the local abundance and species composition of the fishes at this site.

At the Cape Evans wall, the catch consisted predominantly of $P$. borchgrevinki $(74 \%$ in 2010 and $62 \%$ in 2011). Relatively high numbers of Trematomus newnesi Boulenger were also caught at this location, representing $14 \%$ of the catch in 2010 and $30 \%$ of the catch in 2011. Fishing efforts at the McMurdo Station jetty yielded the least numbers of fish (32 in total), and of these $84 \%$ were T. bernacchii and $16 \%$ were Trematomus pennellii Regan (Table I).

The condition of the fishes collected in 2011 was determined by calculation of Fulton's condition index $(K)$ for each species at each collection location (Table II). This index reflects a weight to length relationship and so larger values are associated with more massive fish in a more robust nutritional state. Values varied for some species

Table I. Numbers of fish collected at three sites in McMurdo Sound over multiple collection seasons.

\begin{tabular}{|c|c|c|c|c|c|c|}
\hline \multirow[t]{2}{*}{ Species } & \multicolumn{3}{|c|}{ Inaccessible Island } & \multicolumn{2}{|c|}{ Cape Evans wall } & \multirow{2}{*}{$\begin{array}{l}\text { McMurdo Station jetty } \\
2011\end{array}$} \\
\hline & 2005 & 2010 & 2011 & 2010 & 2011 & \\
\hline Trematomus bernacchii & 231 & 166 & 59 & 16 & 1 & 27 \\
\hline Trematomus newnesi & 0 & 66 & 23 & 18 & 13 & 0 \\
\hline Trematomus nicolai & 0 & 17 & 15 & 0 & 0 & 0 \\
\hline Pagothenia borchgrevinki & 0 & 40 & 19 & 97 & 29 & 0 \\
\hline Total & 233 & 295 & 116 & 131 & 44 & 32 \\
\hline
\end{tabular}


Table II. Weight, total length and Fulton's condition index for fishes caught at three sites in October-November 2011.

\begin{tabular}{|c|c|c|c|c|c|c|c|c|c|}
\hline \multirow[t]{2}{*}{ Species } & \multicolumn{3}{|c|}{ Inaccessible Island } & \multicolumn{3}{|c|}{ Cape Evans wall } & \multicolumn{3}{|c|}{ McMurdo Station jetty } \\
\hline & W & $\mathrm{LT}$ & $K$ & $\mathrm{~W}$ & $\mathrm{LT}$ & $K$ & $\mathrm{~W}$ & $\mathrm{LT}$ & $K$ \\
\hline Trematomus bernacchii & $125.3 \pm 54.7$ & $19.3 \pm 2.4$ & $1.64 \pm 0.6^{*}$ & $\mathrm{n} / \mathrm{a}$ & $\mathrm{n} / \mathrm{a}$ & $\mathrm{n} / \mathrm{a}$ & $144.1 \pm 63.2$ & $19.8 \pm 3.1$ & $1.76 \pm 0.3$ \\
\hline Trematomus newnesi & $75.1 \pm 16.3$ & $18.0 \pm 1.4$ & $1.27 \pm 0.1$ & $105.6 \pm 20.0$ & $20.1 \pm 1.3$ & $1.29 \pm 0.1$ & $\mathrm{n} / \mathrm{a}$ & $\mathrm{n} / \mathrm{a}$ & $\mathrm{n} / \mathrm{a}$ \\
\hline Trematomus nicolai & $67.6 \pm 18.0$ & $16.7 \pm 1.6$ & $1.45 \pm 0.2$ & $\mathrm{n} / \mathrm{a}$ & $\mathrm{n} / \mathrm{a}$ & $\mathrm{n} / \mathrm{a}$ & $\mathrm{n} / \mathrm{a}$ & $\mathrm{n} / \mathrm{a}$ & $\mathrm{n} / \mathrm{a}$ \\
\hline Trematomus pennellii & $\mathrm{n} / \mathrm{a}$ & $\mathrm{n} / \mathrm{a}$ & $\mathrm{n} / \mathrm{a}$ & $\mathrm{n} / \mathrm{a}$ & $\mathrm{n} / \mathrm{a}$ & $\mathrm{n} / \mathrm{a}$ & $35.1 \pm 10.7$ & $13.3 \pm 1.2$ & $1.50 \pm 0.1$ \\
\hline Pagothenia borchgrevinki & $101 \pm 24.0$ & $21.5 \pm 1.98$ & $1.00 \pm 0.1^{*}$ & $84.6 \pm 27.0$ & $19.7 \pm 2.1$ & $1.08 \pm 0.1$ & $\mathrm{n} / \mathrm{a}$ & $\mathrm{n} / \mathrm{a}$ & $\mathrm{n} / \mathrm{a}$ \\
\hline
\end{tabular}

$\mathrm{W}=$ weight $(\mathrm{g}), \mathrm{LT}=$ total length $(\mathrm{cm}), K=$ Fulton's condition index $\left(\mathrm{g} \mathrm{cm}^{-3}\right), \mathrm{n} / \mathrm{a}=$ not applicable.

$* K$ values for this species differ between collection sites, $t$-test $P<0.05$.

between collection sites. The specimens of $T$. bernacchii collected at the McMurdo Station jetty, directly in front of McMurdo Station were larger than those collected at Inaccessible Island (Table II). The specimens of the bald notothen $P$. borchgrevinki collected at the Cape Evans wall had greater $K$ values than those collected at Inaccessible Island (Table II). Interspecific comparisons of $K$ values were not made as body mass to length ratios vary significantly among fishes.

\section{Discussion}

The shallow water species of fishes common to McMurdo Sound, Antarctica, play an important role in the overall ecosystem of the region. While composed of a relatively small number of species, these fishes represent a large biomass and an important link between the invertebrates and other fishes they consume and the top predators, such as toothfish, penguins, seals and toothed whales, which feed upon them (La Mesa et al. 2004, Smith et al. 2007). Therefore, shifts in the condition, abundance and distribution of these fishes is likely to have impacts on the biology and ecology of their prey and predators. These fishes have a long history of scientific study in McMurdo Sound, due both to their ecological importance and to their unique genetic, biochemical and physiological properties, which differentiate them from any other fish fauna. The scientific record is replete with examples of the species represented in the current study being collected in McMurdo Sound, but the total number of each species collected at a particular location during a given season or year is often not reported as these data were not the foci of a given study (for a representative but far from exhaustive set of examples, see Somero \& DeVries 1967, Eastman \& DeVries 1982, Eastman \& DeVries 1997, Hofmann et al. 2000, Franklin et al. 2003, Buckley et al. 2004, Place \& Hofmann 2005, Podrabsky \& Somero 2006, Robinson \& Davison 2008, Buckley \& Somero 2009, Bilyk et al. 2012). The lack of a longitudinal dataset for the small fishes of McMurdo Sound, such as those that exist for the seals and penguins in the region, is also hampered by an under-reporting of precise collection sites and the logistical barriers that hinder comprehensive surveying of aquatic species. The goal of this study was to establish a current baseline of species composition and condition of the shallow water fishes at three commonly sampled locations in McMurdo Sound.

The largest inter-season change in species composition occurred at Inaccessible Island, a location on the western side of Erebus Bay and within the vicinity of Weddell seal breeding colonies. In 2005, this site was dominated by a single species, T. bernacchii, but in 2010 and 2011, three to four other trematomid species were caught as were considerable numbers of $P$. borchgrevinki (Fig. 1). Specimens of $T$. newnesi, abundant in large numbers in 2010 and 2011, but absent in 2005, were collected at Inaccessible Island in 1995 (Eastman \& DeVries 1997) and in 1998 (Barrera-Oro et al. 2012). It is possible that current species compositions at this location are similar to those that existed prior to the 2000s. This species was also collected at the jetty in front of McMurdo Station in 1991, 1992 and 1994 (Eastman \& DeVries 1997), but appear now to be absent from this location.

At the Cape Evans wall, the catch included large numbers of $P$. borchgrevinki although this directly reflects the amount of time devoted to fishing in the water column and the cryopelagic zone vs on the bottom. Pagothenia borchgrevinki spend much of their time in and under the brash ice at the seawater/sea ice interface. Relatively large numbers of $T$. newnesi were also collected. This species is semi-pelagic and therefore may overlap in the water column with $P$. borchgrevinki (Richardson 1975). The noteworthy aspect of the Cape Evans wall data is the interannual similarity in the catch in 2010 and 2011, a within-site consistency that was also observed in these years at Inaccessible Island. No fishing effort was made at the Cape Evans wall site in 2005, but the 2010-11 data provide a background for future efforts at this location, which is consistently growing as a research site of interest for a variety of international research programmes focused on fishes and other marine biota.

The catch at the McMurdo Station jetty in 2011 yielded the fewest individuals and consisted of only two species, $T$. bernacchii and T. pennellii. Whether the relative scarcity of fishes at this site is due to factors that arise from its proximity to the station is an open question and deserves further study. There were large quantities of fish larvae sighted in the water column at this location in 2011 perhaps 
heralding new recruitment of fishes to the site (personal observation).

The physiological condition of the fish collected in this study was similar for a given species between collection locations except in two cases (Table II). The $K$ values for $T$. bernacchii and $P$. borchgrevinki were lower for individuals at Inaccessible Island than for their conspecifics collected at the McMurdo Station jetty and the Cape Evans wall, respectively. Higher $K$ values, reflecting greater body mass to length ratios, are generally reflective of a better nutritional state (Weatherly \& Gill 1987, Bolger \& Connolly 1989, Busacker et al. 1990, Fenaughty 2006). The lower $K$ values at Inaccessible Island, therefore, may reflect relatively poor prey availability or quality at this site.

The changes in fish species composition at Inaccessible Island between 2005 and the latter two collection years occurred following a period of increasing pressure from commercial fishing in the Ross Sea focused on the Antarctic toothfish, Dissostichus mawsoni, which traditionally had little or no impact in the extreme southern region of McMurdo Sound (Ainley et al. 2012a). From the inauguration of the fishery in the 1996-97 summer to 2005, the annual catch of Ross Sea toothfish rose steadily, reaching the maximum allowable catch (3500 tonnes) in 2006, and has remained steady at that level (Ainley et al. 2012a). This fishing effort has coincided with a marked depletion in the number of this species in McMurdo Sound (Ainley et al. 2012b). Since the early 1970s, scientific collection has resulted in approximately 4500 specimens of the Antarctic toothfish being tagged and released in the sound (Ainley et al. 2012b). Since 2006, there has been a documented reduction in the number of toothfish in the sound, with recent fishing efforts resulting in no adult specimens being collected (Ainley et al. 2012b). It is possible that the removal of predation pressure on smaller fish species by D. mawsoni in recent years has had an impact on the relative abundances of these prey species.

The change in small fish species composition may be an effect of changes in other components of the local food web. Weddell seals are piscivorous and have been observed on numerous occasions preying on toothfish, both visually and via seal-mounted cameras, and the importance of toothfish to the diet of these seals is a subject of current discussion (Dearborn 1965, Davis et al. 1999, Kim et al. 2005, Ponganis \& Stockard 2007). However, there is evidence that seals will feed on small shallow water fishes as well. Burns et al. (1998) found that $88.4 \%$ of adult Weddell seal scats contained $P$. antarcticum vertebrae and $2.7 \%$ contained those of members of the genus Trematomus. Juvenile seals were observed to be foraging on the bottom and analysis of their scat confirmed that they were consuming fishes and concentrating on Trematomus species. At White Island, Trematomus spp. represented a large portion of the available prey species for the isolated population of Weddell seals that reside there (Dearborn 1965, Castellini et al. 1984). Therefore, it is possible that in the absence of toothfish, Weddell seals may focus on a diet composed more of shallow water fishes, although this remains to be confirmed with other methodology such as scat analysis, which should include modern DNA-based techniques for identifying specific prey species.

As water temperatures in southern McMurdo Sound have not yet begun to warm as they have elsewhere in the Southern Ocean and vary little from $-1.86^{\circ} \mathrm{C}$ annually (Hunt et al. 2003), rising water temperature is not a likely cause of the species shift. It is noteworthy that the changes in species composition of nearshore species reported here followed an accrual of multi-year sea ice throughout McMurdo Sound during the 2001-05 period, ice that failed to break up and blow out into the Ross Sea as it traditionally does due to the presence of iceberg B-15 at the entrance to the sound during that period. The presence of multi-year ice displaced many Weddell seals from the area owing to a reduction in the number of cracks in the sea ice for ocean-air access (Siniff et al. 2008). After B-15 broke up and departed, the seals quickly returned in 2006 (Siniff et al. 2008). A potential scenario therefore is that during the period of reduced predation by seals due to the decline in their numbers related to the effects of B-15, T. bernacchii flourished at Inaccessible Island, and upon the return of the seals to the area, this species became an important prey item as the toothfish was no longer available. This may in turn have caused the shift in the composition of shallow water fishes observed in this study.

Clearly, identifying the factors that drive and define fish population dynamics and their relative importance in McMurdo Sound warrants future study. Given the unique nature and the open questions still to be answered about continental Antarctic marine habitats, increased monitoring of the state of critical components of the food web such as fishes is imperative. Current baseline information on interannual dynamics of fish species composition and distributions is necessary for predictions concerning the effects of coming changes in the abiotic properties of the Southern Ocean and the impact of commercial fisheries.

\section{Acknowledgements}

The 2010 and 2011 collections were supported by NSF grant ANT-0944743 to BAB. The author thanks I.M. Sleadd, A.L. Kelley, D.O. Hassumani, A.J. Barden and M. Lee for field assistance during these seasons. The author would also like to gratefully acknowledge Dr G.E. Hofmann and the members of B-134-M (J.M. Dutton, E.A. Hoagland, C.J. Osovitz and M.L. Zippay) for their excellent assistance in the field collections of the 2005 season, which were supported under NSF Postdoctoral Award ANT-0443754 to BAB and NSF grant ANT-0440799 to GEH. The author would like to thank two reviewers for their helpful comments on the manuscript. 


\section{References}

Ainley, D.G. \& SinIfF, D.B. 2009. The importance of Antarctic toothfish as prey of Weddell seals in the Ross Sea: a review. Antarctic Science, 21, 317-327.

Ainley, D.G., Brooks, C.M., Eastman, J.T. \& Massaro, M. 2012a. Unnatural selection of Antarctic toothfish in the Ross Sea, Antarctica. In Huettmann, F., ed. Protection of the three poles. Tokyo: Springer, 53-75.

Ainley, D.G., Nur, N., Eastman, J.T., Ballard, G., Parkinson, C.L., Evans, C.W. \& DeVries, A.L. 2012b. Decadal trends in abundance, size and condition of Antarctic toothfish in McMurdo Sound, Antarctica, 1972-2011. Fish and Fisheries, 10.1111/j.1467-2979.2012.00474.x.

Barrera-Oro, E., Eastman, J.T. \& Moreira, E. 2012. Phenotypic plasticity in the Antarctic nototheniid fish Trematomus newnesi: a guide to the identification of typical, large mouth and intermediate morphs. Polar Biology, 35, 1047-1056.

Bilyk, K.T., Evans, C.W. \& DeVries, A.L. 2012. Heat hardening in Antarctic notothenioid fishes. Polar Biology, 35, 1447-1451.

Bolger, T. \& Connolly, P.L. 1989. The selection of suitable indices for the measurement and analysis of fish condition. Journal of Fish Biology, 34, 171-182.

Buckley, B.A. \& Somero, G.N. 2009. cDNA microarray analysis reveals the capacity of the cold adapted Antarctic fish Trematomus bernacchii to alter gene expression in response to heat stress. Polar Biology, 32, 403-415.

Buckley, B.A., Place, S.P. \& Hofmann, G.E. 2004. Regulation of heat shock genes in isolated hepatocytes from an Antarctic fish, Trematomus bernacchii. Journal of Experimental Biology, 207, 3649-3656.

Burns, J.M., Trumble, S.J., Castellini, M.A. \& Testa, J.W. 1998. The diet of Weddell seals in McMurdo Sound, Antarctica as determined from scat collections and stable isotope analysis. Polar Biology, 19, 272-282.

Busacker, G.P., Adelman, I.R. \& Goolish, E.M. 1990. Growth. In Schreck, C.B. \& MoyLe, P.B., eds. Methods for fish biology. Bethesda, MD: American Fisheries Society, 363-387.

Castellini, M.A., Davis, R.W., Davis, M. \& Horning, M. 1984. Antarctic marine life under the McMurdo ice shelf at white island: a link between nutrient influx and seal population. Polar Biology, 2, 229-231.

Cheng, C-H.C. \& Detrich, H.W. 2007. Molecular ecophysiology of Antarctic notothenioid fishes. Philosophical Transactions of the Royal Society, B362, 2215-2232.

Davis, R.W., Fuiman, L.A., Williams, T.M., Collier, C.O., Hagey, W.P., Kanatous, S.B., Kohin, S. \& Horning, M. 1999. Hunting behavior of a marine mammal beneath the Antarctic fast ice. Science, 283, 993-996.

Dearborn, J.H. 1965. Food of Weddell seals at McMurdo Sound, Antarctica. Journal of Mammalogy, 40, 37-41.

Eastman, J.T. 2005. The nature of the diversity of Antarctic fishes. Polar Biology, 28, 93-107.

Eastman, J.T. \& DeVries, A.L. 1982. Buoyancy studies of notothenioid fishes in McMurdo Sound, Antarctica. Copeia, 2, 385-393.
Eastman, J.T. \& DeVRies, A.L. 1997. Biology and phenotypic plasticity of the Antarctic nototheniid fish Trematomus newnesi in McMurdo Sound. Antarctic Science, 9, 27-35.

Eastman, J.T. \& McCune, A.L. 2000. Fishes on the Antarctic shelf: evolution of a marine species flock. Journal of Fish Biology, 57, 84-102.

Fenaughty, J.M. 2006. Geographical differences in the condition, reproductive development, sex ratio and length distribution of Antarctic toothfish (Dissostichus mawsoni) from the Ross Sea, Antarctica (CCAMLR Subarea 88.1). CCAMLR Science, 13, 27-45.

Franklin, C.E., Wilson, R.S. \& Davison, W. 2003. Locomotion at $-1.0^{\circ} \mathrm{C}$ : burst swimming performance of five species of Antarctic fish. Journal of Thermal Biology, 28, 59-65.

Hofmann, G.E., Buckley, B.A., Airaksinen, S., Keen, J.E. \& Somero, G.N. 2000. Heat shock protein expression is absent in the Antarctic fish, Trematomus bernacchii (Family Nototheniidae). Journal of Experimental Biology, 203, 2331-2339.

Hunt, B.M., Hoefling, K. \& Cheng, C.-H.C. 2003. Annual warming episodes in seawater temperatures in McMurdo Sound in relationship to endogenous ice in notothenioid fish. Antarctic Science, 15, 333-338.

Kim, S.L., Conlan, K., Malone, D.P. \& Lewis, C.V. 2005. Possible food caching and defence in the Weddell seal: observations from McMurdo Sound, Antarctica. Antarctic Science, 17, 71-72.

La Mesa, M., Eastman, J.T. \& Vacchi, M. 2004. The role of notothenioid fish in the food web of the Ross Sea shelf waters: a review. Polar Biology, 27, 321-338.

Petricorena, Z.L.C. \& Somero, G.N. 2007. Biochemical adaptations of notothenioid fishes: comparisons between cold temperate South American and New Zealand species and Antarctic species. Comparative Biochemistry and Physiology, 147A, 799-807.

Place, S.P. \& Hofmann, G.E. 2005. Constitutive expression of a stressinducible heat shock protein gene, hsp70, in phylogenetically distant Antarctic fish. Polar Biology, 28, 261-267.

Podrabsky, J.E. \& Somero, G.N. 2006. Inducible heat tolerance in Antarctic notothenioid fishes. Polar Biology, 30, 39-43.

Ponganis, P.J. \& Stockard, T.K. 2007. The Antarctic toothfish: how common a prey for Weddell seals? Antarctic Science, 19, 441-442.

Richardson, M.G. 1975. The dietary composition of some Antarctic fish. British Antarctic Survey Bulletin, No. 41-42, 113-120.

Robinson, E. \& Davison, W. 2008. Antarctic fish can survive prolonged exposure to elevated temperatures. Journal of Fish Biology, 73, $1676-1689$.

Siniff, D.B., Garrott, R.A., Rotella, J.J., Fraser, W.R. \& Ainley, D.J. 2008. Projecting the effects of environmental change on Antarctic seals. Antarctic Science, 20, 425-435.

Smith JR, W.O., Ainley, D.G. \& Cattaneo-Vetti, R. 2007. Marine ecosystems: the Ross Sea. Philosphical Transactions of the Royal Society, B362, 95-111.

Somero, G.N. \& DeVries, A.L. 1967. Temperature tolerance of some Antarctic fishes. Science, 156, 257-258.

Weatherly, A.H. \& Gill, H.S. 1987. The biology of fish growth. London: Academic Press, 443 pp. 